\title{
Periphyton biomass accrual rate changes over the colonization process in a shallow mesotrophic reservoir
}

\author{
Mudanças na taxa de acumulação de biomassa ao longo do processo de colonização do \\ perifíton em um reservatório mesotrófico raso
}

Mayara Ribeiro Casartelli ${ }^{1 *}$, Gabriela de Jesus Lavagnolli ${ }^{2}$ and Carla Ferragut ${ }^{2}$

\begin{abstract}
${ }^{1}$ Programa de Pós-graduaçáo em Biodiversidade Vegetal e Meio Ambiente, Instituto de Botânica, Núcleo de Pesquisas em Ecologia - NPE, Avenida Miguel Stéfano, 3031, Água Funda, CEP 04301-902, São Paulo, SP, Brazil

${ }^{2}$ Instituto de Botânica, Núcleo de Pesquisas em Ecologia - NPE, Avenida Miguel Stéfano, 3031, Água Funda, CEP 04301-902, Sáo Paulo, SP, Brazil

*e-mail: mayaracasartelli@gmail.com
\end{abstract}

Cite as: Casartelli, M.R., Lavagnolli, G.J. and Ferragut, C. Periphyton biomass accrual rate changes over the colonization process in a shallow mesotrophic reservoir. Acta Limnologica Brasiliensia, 2016, vol. 28, e9.

Abstract: Aim: We identified and analyzed the developmental phases (exponential and loss) of periphyton on artificial substrates based on biomass accrual rate in dry and rainy seasons in a shallow mesotrophic reservoir (Ninfeias Reservoir, Parque Estadual das Fontes do Ipiranga, São Paulo, Brazil). We evaluated the colonization time required for the developmental phase to change, as well as related limnological variables. Methods: Samplings were carried out weekly, totaling 98 days of substrates exposure. We analyzed the limnological and periphyton variables (chlorophyll $a$, ash free dry mass, net and gross accrual rate). Results: Maximum biomass occurred on the 42nd day in rainy season and on the 98th day in dry season. In the rainy season, the exponential phase of biomass accrual continued until the 28 th day of colonization, followed by a fluctuation phase (35th to 77 th day) and then a loss phase (84th to 98th days). In the dry season, the exponential phase continued until the 35 th day, followed by a loss phase (42th to 63rd day) and then a fluctuation phase (70th and 77 th day). In the same season, we observed the beginning of a new exponential phase (84th to 98th day). The biomass peak was recorded on the 42nd colonization day in the rainy season and on the 98th day in the dry season. Biomass and gross and net accrual were higher in the dry season than in the rainy season. Conclusions: Periphyton biomass and net and gross accrual rates were higher during the dry season, which was characterized by high total nitrogen concentration, water transparency and low rainfall. We concluded that periphyton biomass accrual and the duration of the developmental phases (exponential, loss and fluctuation) changed with variations in limnological conditions in each climatic period in the tropical shallow reservoir studied.

Keywords: artificial substrates; ash free dry mass; chlorophyll $a$; gross and net accrual rate.

Resumo: Objetivo: Nós identificamos e analisamos as fases de desenvolvimento do perifíton (exponencial e perda) em substrato artificial com base na taxa de acumulação de biomassa no período seco e chuvoso em um reservatório mesotrófico raso (Lago das Ninfeias, Parque Estadual das Fontes do Ipiranga, São Paulo, Brasil). Foi avaliado o tempo de colonização requerido para a mudança de fase de desenvolvimento, a qual também foi relacionada com as variáveis limnológicas. Métodos: Foram analisadas variáveis limnológicas e do perifíton (clorofila- $a$, massa seca livre de cinzas, taxa acumulação líquida e bruta) durante 98 dias de exposição do substrato. Resultados: No período 
chuvoso, a fase exponencial de acumulação de biomassa foi até o $28^{\circ}$ dia de colonização, sendo seguida por uma fase de flutuação $\left(35^{\circ}-77^{\circ} \mathrm{dia}\right)$ e fase de perda $\left(84^{\circ}-98^{\circ} \mathrm{dia}\right)$. Na estação seca, a fase exponencial foi até o $35^{\circ}$ dia, sendo seguida por uma fase de perda ( $42^{\circ}-63^{\circ}$ dia) e de flutuação $\left(70^{\circ}\right.$ dia e $\left.77^{\circ} \mathrm{dia}\right)$. Nesta estaçáo, observou-se o início de uma nova fase exponencial de acumulação de biomassa $\left(84^{\circ}\right.$ ao $98^{\circ}$ dia). O pico de biomassa foi registrado no $42^{\circ}$ dia no período chuvoso e no $98^{\circ}$ dia no período seco. A biomassa e a taxa de acumulação bruta e líquida foram maiores no período seco do que no chuvoso. Conclusáo: A biomassa e a taxa de acumulaçáo líquida e bruta do perifíton foram maiores no período seco, o qual foi caracterizado pela alta concentração de nitrogênio total e transparência da água e baixa pluviosidade. Concluímos que a taxa de acumulação de biomassa e duração das fases de desenvolvimento (exponencial, perda e flutuação) do perifíton mudaram com condiçóes limnológicas em cada período climático no reservatório tropical raso estudado.

Palavras-chave: substrato artificial; massa seca livre de cinzas; clorofila $a$; taxa de acumulação bruta e líquida.

\section{Introduction}

The periphyton biomass is temporally variable due to accumulation processes, losses and disturbances, which can restart the community development (Stevenson, 1996). The periphyton biomass tends to increase exponentially until reaching a maximum during colonization and later tends to decrease due to loss of biomass (Biggs, 1996). According to Biggs (1996), the pattern of periphyton biomass accumulation can reflect environmental changes because the accrual phase is controlled primarily by resource (nutrients and light) availability, while disturbances (e.g. instability of the substrate, current velocity) and grazing can act primarily during the loss phase.

There is consensus that 2 to 4 weeks of colonization time is the optimal range for maximum periphytic biomass development in freshwater systems, including tropical lakes and reservoirs (Cattaneo \& Amireault, 1992; Bicudo et al., 1995). However, the relationship between the maximum biomass and colonization time is very dependent on environmental conditions, which have a direct influence on periphyton dynamics (Vadeboncoeur \& Steinman, 2002). Periphyton biomass measurements at specific colonization times can underestimate the environment's ability to support high primary production (Stevenson, 1996; Vadeboncoeur \& Steinman, 2002).

The identification of maximum accrual of periphyton biomass may improve the understanding of the community's role in the production of organic matter in shallow tropical lakes and reservoirs, as observed in lotic ecosystems (e.g. Biggs, 1996, 1998). In Brazilian lentic ecosystems, most studies on periphyton succession and colonization were performed using time of less than 35 days of colonization (e.g. Vercellino \& Bicudo, 2006; França et al., 2009), with only a few exceptions
(Moschini-Carlos et al., 2000). In this study, the periphyton accumulation (net and gross accrual rate) on artificial substrates was measured until consecutive losses were identified during the colonization process. We evaluated the periphyton biomass and accrual rates during colonization to identify the developmental phases (exponential and loss) during the dry and rainy seasons. We also evaluated the colonization time required for the developmental phase to change, as well as related limnological variables.

\section{Material and Methods}

\subsection{Study area}

This research was conducted in the Ninfeias Reservoir, which is an artificial reservoir designed for landscaping purposes inside the Parque Estadual das Fontes do Ipiranga (2339'15.60"S, 463'22.83”W) in São Paulo, São Paulo State, Brazil. This reservoir is a shallow mesotrophic and polymictic ecosystem with a surface area of $5433 \mathrm{~m}^{2}$ and a volume of $7170 \mathrm{~m}^{3}$. The mean depth is $1.32 \mathrm{~m}$ with a maximum depth of $3.6 \mathrm{~m}$, and it has a mean theoretical residence time of 7 days (Bicudo et al., 2002).

\subsection{Sampling and analyses}

Weekly samplings were performed for determination of limnological variables and periphyton on artificial substrates at two sites in littoral zone, where there was a predominance of Nymphaea spp.. Samplings were carried out in the rainy (Oct/08/2010 to Jan/14/2011) and dry seasons (June/10/2011 to September/09/2011).

Two experimental apparatus for periphyton colonization were placed at distance of 10 meters from each other to include spatial variability. The experimental apparatus consisted of a wood frame with 100 glass slides $(76 \mathrm{~mm} \times 26 \mathrm{~mm})$ 
positioned vertically and submerged to a depth of $30 \mathrm{~cm}$ (to avoid photoinhibition). The apparatus height prevented the shading of macrophytes, mainly leaves of Nymphaea spp.. The colonized glass slides were taken randomly from experimental apparatus. In the laboratory, periphyton was removed from the substrate by scraping and rinsing with distilled water.

We sampled water near the each experimental apparatus to determine the chemical and physical variables $(n=2)$ on each sampling day. On those days, we determined underwater radiation (Licor LI-250A), water transparency (Secchi disk), temperature, conductivity (Digimed conductivimeter), dissolved oxygen (Golterman et al., 1978), alkalinity (Golterman \& Clymo, 1971), $\mathrm{pH}$ (pHmeter Digimed) and free $\mathrm{CO}_{2}$ and bicarbonate $\left(\mathrm{HCO}_{3}\right)$. Unfiltered water samples were used to determine the total nitrogen (TN) and phosphorus (TP) (Valderrama, 1981) within, at most, 30 days of the collection date. Further, air temperature and rainfall values were obtained from the Meteorological Station of the Instituto Astronômico e Geofísico da Universidade de São Paulo (USP, 2015).

We determined chlorophyll a (corrected for phaeophytin) from periphyton samples filtered on glass-fiber filters (GF/F Whatman, Maidstone, UK), following 24 h extraction with $90 \%$ ethanol in the dark (Sartory \& Grobbelaar, 1984). We also determined ash-free dry mass (AFDM) by filtering periphyton samples on pre-calcined and weighed glass-fiber filters (GF/F Whatman). Subsequently, we weighed the samples every 24 hours until obtaining a constant mass so as to determine the dry mass. Subsequently, we calcined $\left(500{ }^{\circ} \mathrm{C}, 1 \mathrm{~h}\right)$ and weighed the samples to determine the ash-free dry mass (APHA, 2005). We determined gross and net accrual rate of periphyton biomass $\left(\mathrm{g} \mathrm{m}^{-2} \mathrm{~d}^{-1}\right)$ to assess the algal biomass changes (Stevenson, 1996).

\subsection{Data analisys}

Principal Component Aanalysis (PCA) was performed to reduce the dimensionality of abiotic data. PCA was performed using the covariance matrix and the data transformed by ranging $\left[\left(\mathrm{x}^{-\mathrm{x}_{\min }}\right) /\left(\mathrm{X}_{\max }-\mathrm{x}_{\min }\right)\right]$. The randomization test (999 permutations) was used to evaluated the PCA interpretation dimension $(p<0.05)$. PCA was done using PCORD 5.15 for Windows (McCune \& Mefford, 2011).

\section{Results}

\subsection{Climatic variables}

The accumulated rainfall was higher during the rainy season $(853 \mathrm{~mm})$ than during the dry season $(142 \mathrm{~mm})$ (Figure 1). High cumulative rainfall occurred on the 53rd, 66th, 67th, 94th and 98th day of the rainy season $(>40 \mathrm{~mm})$. In contrast, during the dry season, rainfall was low with the highest value occurring on the 89 th day $(34.8 \mathrm{~mm})$. The daily average temperature values were higher during the rainy season than those measured during the dry season (Figure 1).

\subsection{Limnological variables}

On average, the limnological condition was characterized by high conductivity, TP and subaquatic radiation during the rainy season (Table 1). In contrast, TN concentration was higher in the dry season than in the rainy season. During the rainy season, the sampling period of 7 to 42 days showed the highest free $\mathrm{CO}_{2}$, dissolved oxygen and TP concentration, while the period from day 56 to day 98 showed the greatest $\mathrm{TN}, \mathrm{pH}$ and

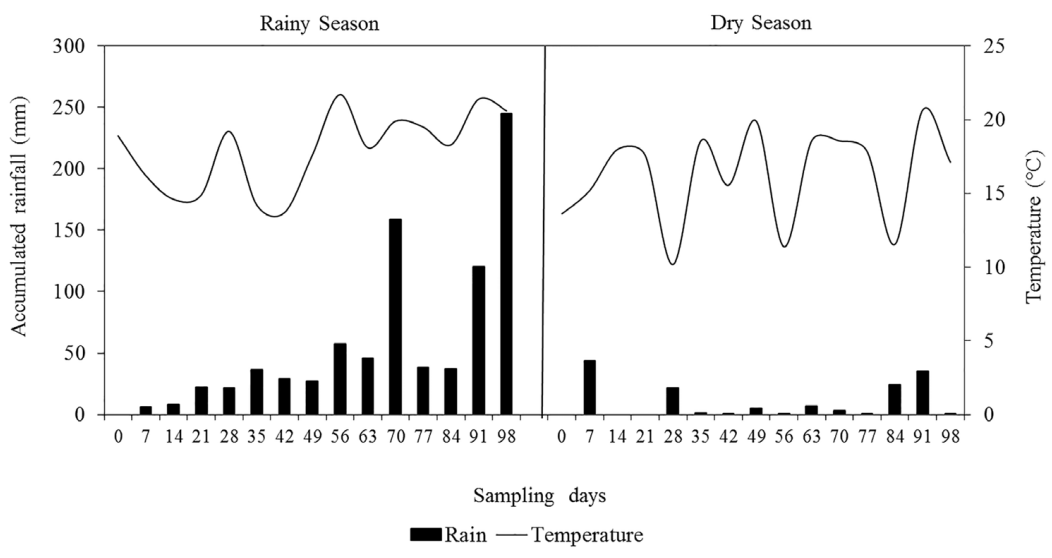

Figure 1. Average daily accumulated rainfall and air temperature during study period. 
temperature values. During the dry season, dissolved oxygen, free $\mathrm{CO}_{2}$, TN and TP concentrations were higher from the 63rd to the 98th day of the sampling period.

PCA explained $55.3 \%$ of limnological data variability in the first two ordination axes (Figure 2). Axis 1 ordered the sample units of the rainy season on the positive side and the dry season on the negative side. On the negative side of axis 1 , the sampling units were associated with higher $\mathrm{HCO}_{3}$ and water transparency (Pearson correlation: $r=-0.703$ and -0.893 , respectively). On the positive side, the sampling units from the rainy season were more associated with higher values of total phosphorus and temperature (Pearson correlation: $r=0.592$ and 0.819 , respectively). Axis 1 represented the seasonal variation in the limnological conditions at the sampling sites during the study period. The axis 2 ordered sampling units according to TN concentration (Pearson correlation: $r=0.797$ ).

\subsection{Periphyton}

Periphyton photosynthetic biomass (chlorophyll $a$ ) increased exponentially until the $28^{\text {th }}$ day of colonization during the rainy season and until the 35th day during the dry season (Figure 3A).

Table 1. Limnological variables ranges and, between parentheses, mean and standard deviation $(n=14)$ in aquatic macrophyte stands during the dry and rainy seasons.

\begin{tabular}{lcc}
\hline Abiotic Variables & Dry Season & Rainy Season \\
\hline Alkalinity $\left(\mathrm{mEq} \mathrm{L}^{-1}\right)$ & $0.21-0.32(0.27 \pm 0.04)$ & $0.24-0.31(0.28 \pm 0.02)$ \\
Free $\mathrm{CO}_{2}\left(\mathrm{mg} \mathrm{L}^{-1}\right)$ & $1.1-46.4(10.8 \pm 10.9)$ & $0.1-6.1(14.4 \pm 14.9)$ \\
Conductivity $\left(\mu \mathrm{S} \mathrm{cm}^{-1}\right)$ & $40.2-55.0(46.3 \pm 3.6)$ & $12.4-57.6(50.6 \pm 11.8)$ \\
Total Phosphorus $\left(\mu \mathrm{g} \mathrm{L}^{-1}\right)$ & $33.0-191.6(78.6 \pm 50.1)$ & $58.3-142.3(101.4 \pm 24.4)$ \\
Total Nitrogen $\left(\mu \mathrm{L}^{-1}\right)$ & $235.3-1306.4(718.4 \pm 424.3)$ & $338.8-1217.0(637.0 \pm 266.0)$ \\
Dissolved oxygen $\left(\mathrm{mg} \mathrm{L}^{-1}\right)$ & $2.4-7.1(4.9 \pm 1.1)$ & $2.0-7.1(4.0 \pm 1.5)$ \\
$\mathrm{pH}$ & $6.1-7.4(6.6 \pm 0.4)$ & $5.7-8.4(6.6 \pm 0.6)$ \\
Subaquatic Radiation $(\mu \mathrm{mol} \mathrm{s}$ & $202.2-1457.1(739.8 \pm 368.3)$ \\
Water Temperature $\left({ }^{\circ} \mathrm{C}\right)$ & $124.3-1184.5(585.5 \pm 359.6)$ & $20.6-25.5(23.0 \pm 1.7)$ \\
\hline
\end{tabular}

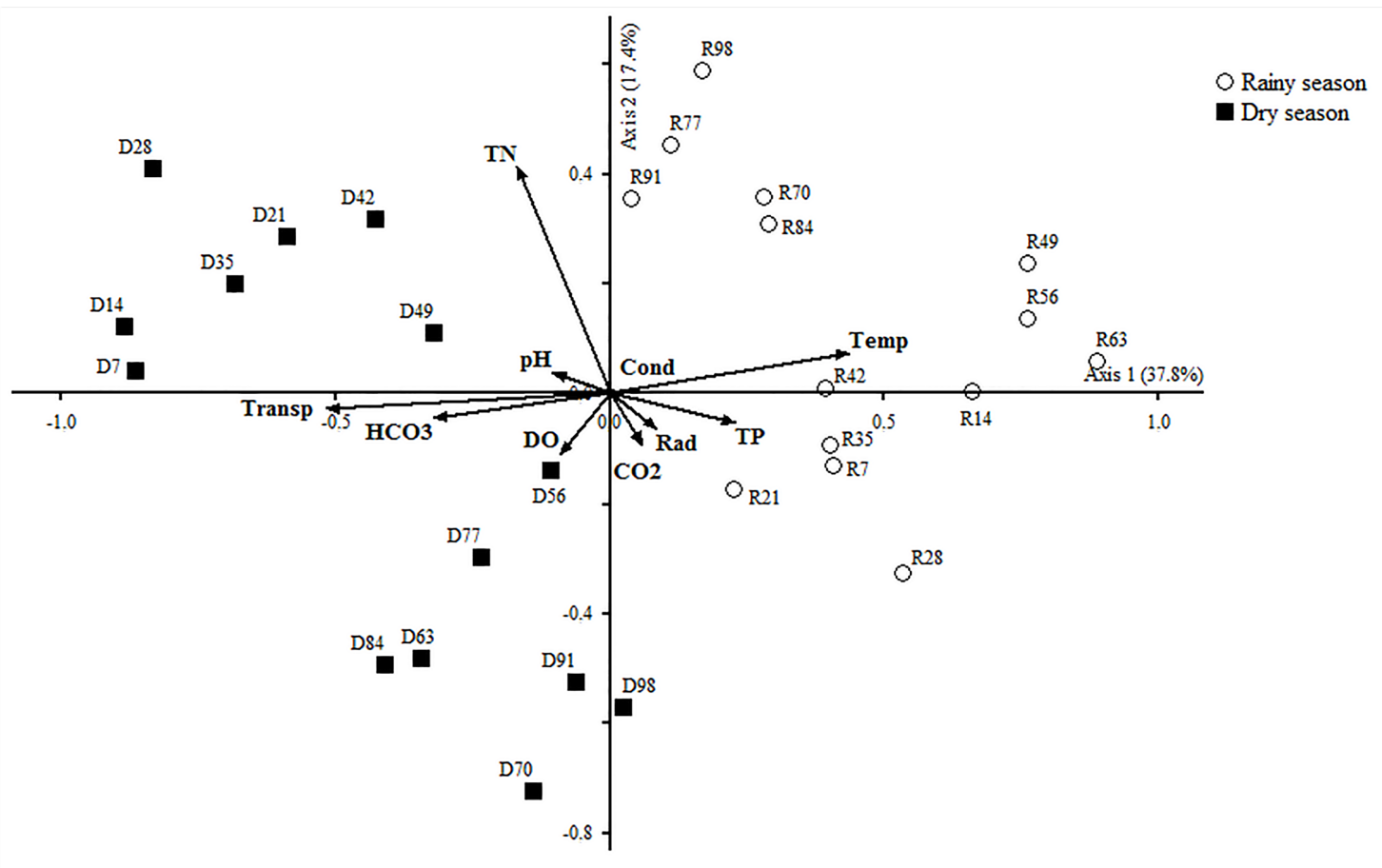

Figure 2. Principal component analysis (PCA) of the limnological variables in Ninfeias reservoir in the rainy and dry seasons. Score abbreviation: first letter refers to climatic season (D: dry season, R: rainy season) and numbers to sampling day. Vector abbreviation: Cond: conductivity; TN: total nitrogen; TP: total phosphorus; Temp: water temperature; Transp: water transparency; $\mathrm{CO} 2$ : free $\mathrm{CO}_{2}$; $\mathrm{HCO} 3$ : bicarbonate; Rad: subaquatic radiation; $\mathrm{pH}$ : hydrogenionic potential; DO: dissolved oxygen. 
A.

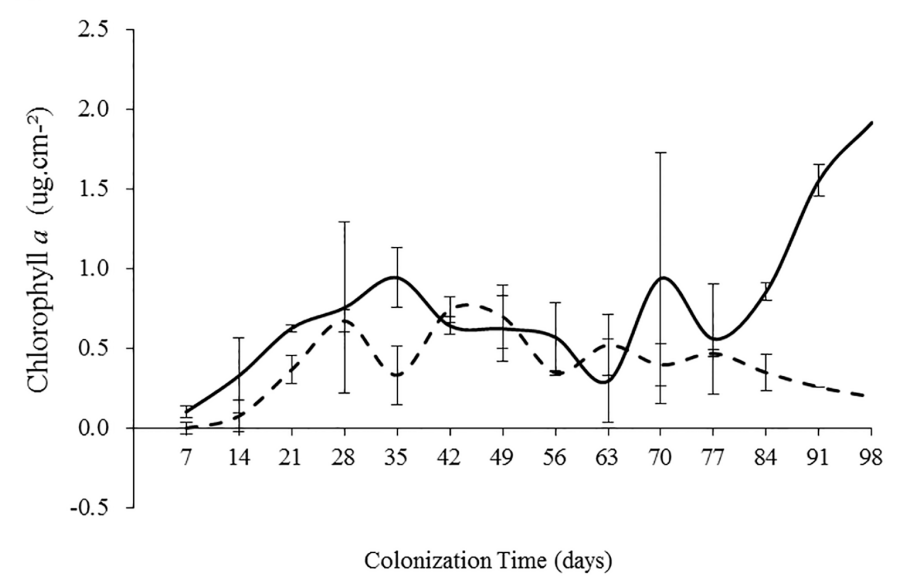

Colonization Time (days)

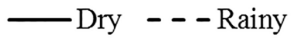

B.

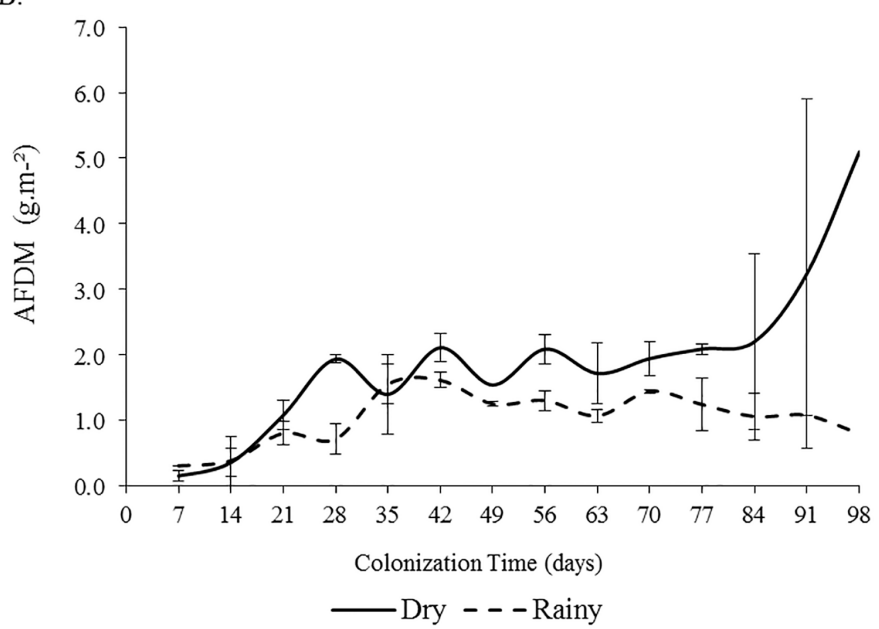

Figure 3. Temporal variation of periphytic biomass $(n=2$; chlorophyll $a(A)$ and AFDM (B)) over the colonization process in the rainy and dry season in a shallow mesotrophic reservoir.

Periphyton AFDM increased exponentially until the 21 st day of colonization during the rainy season, and until the 28th day during the dry season (Figure 3B). The maximum values for AFDM and chlorophyll $a$ occurred on the 42nd day of the rainy season and on the 98th day of the dry season. Periphyton AFDM and chlorophyll $a$ exhibited a similar pattern of change during the colonization process.

Considering the periphyton photosynthetic biomass accrual for the 98 days of colonization, we observed that gross and net accrual rate was 1.8 and 5.2 times higher during the dry season than during the rainy season, respectively (Figure 4). Gross and net accumulation rates of periphyton photosynthetic biomass varied over the colonization time in the dry and rainy seasons (Figure 5A-B). During the rainy season, the exponential phase of

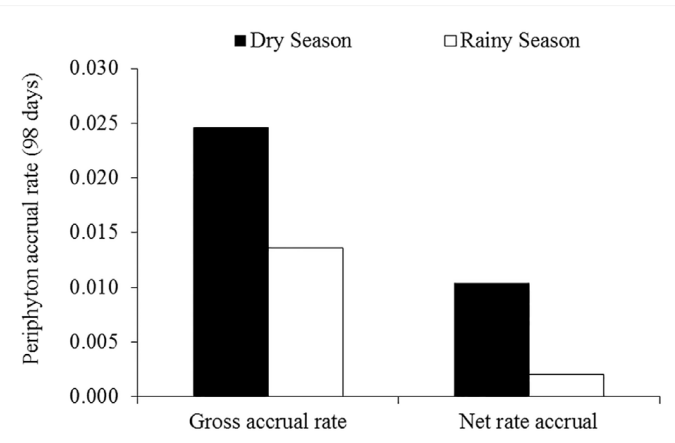

Figure 4. Periphyton gross and net accrual rate during 98 days of colonization in a shallow mesotrophic reservoir.

biomass accrual was from the 7 th to 28 th day of colonization, subsequently a fluctuation phase was initiated (35th to 77 th day) and following the 84th day the biomass loss phase began. During the dry 

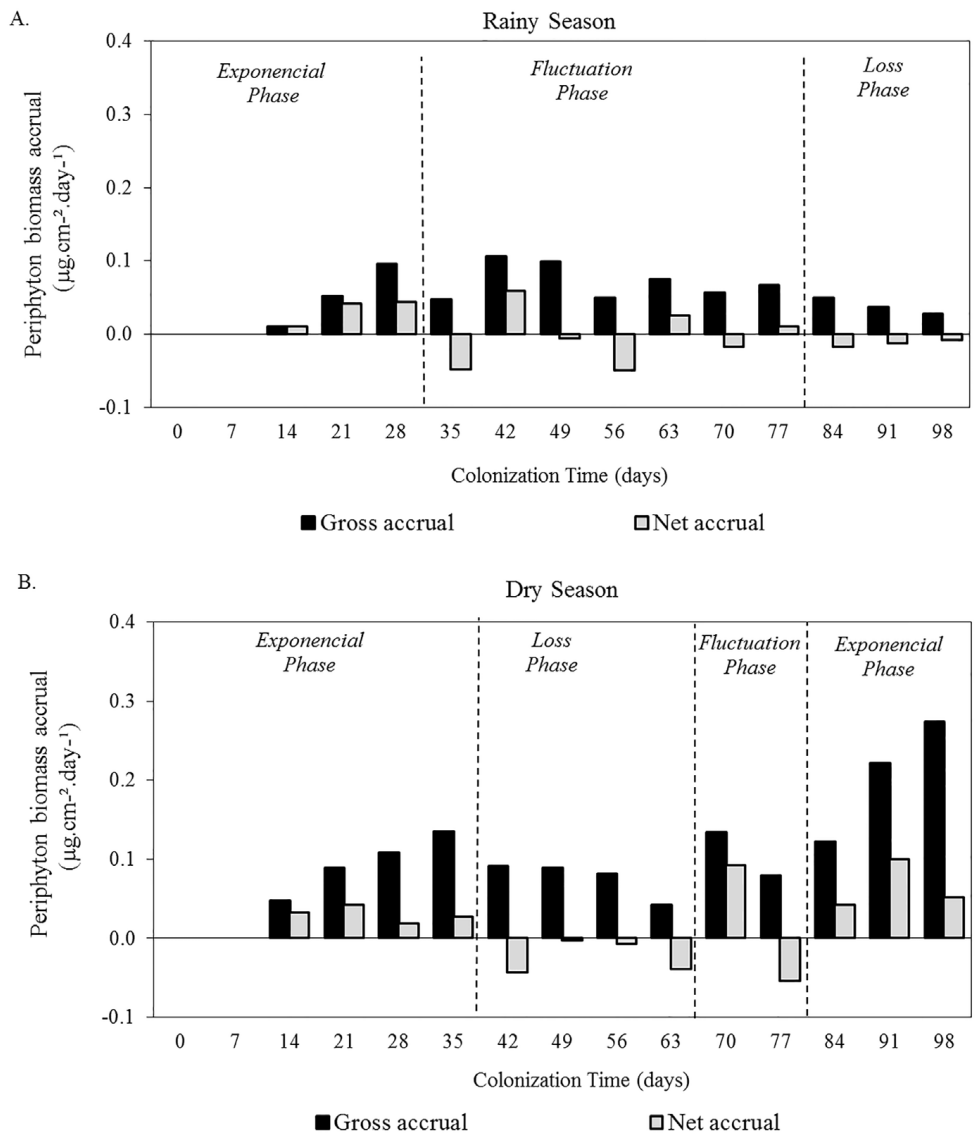

Figure 5. Periphyton gross and net accrual rate (chlorophyll $a$ ) over the colonization process in the rainy (A) and dry (B) seasons in a shallow mesotrophic reservoir.

season, the biomass accrual phase was from the 7 th to the 35 th day of colonization, subsequently a biomass loss phase was initiated (42nd to 63rd day), then there was an accumulation fluctuation phase (70th to 77 th day), finalizing with a new phase of exponential increase in biomass (84th to 98th day).

\section{Discussion}

Our findings showed that periphyton biomass (AFDM and chlorophyll a) increased with colonization time in both the dry and rainy seasons, as widely described in the literature (e.g. Cattaneo \& Amireault, 1992; Vercellino \& Bicudo, 2006). However, periphyton biomass accumulation was strongly influenced by seasonality, which acted on both variability and maximum rate of biomass accrual in the studied reservoir.

The highest net and gross accrual rate of periphyton biomass was found during the dry season, suggesting that environmental conditions were more favorable for periphyton development. During the rainy season, there was a high loss of periphytic biomass, especially after high cumulative rainfall $(>29 \mathrm{~mm}$ ). This season was characterized by high and constant rainfall, which certainly led to a large loss of biomass due to the detachment of periphyton from substrates. Periphytic biomass is temporally variable because of successive accumulation, autogenic sloughing, and disturbances that reset community development (Biggs, 1996). Various types of disturbance can lead to loss of periphytic biomass, including heavy rainfall events. For instance, Felisberto $\&$ Rodrigues (2005) reported that heavy rain (287.3-226.2 mm) caused loss of periphytic biomass in a tropical reservoir. Furthermore, development of periphyton can be negatively influenced by increases in turbidity caused by particle material flow after large rainfall events (Hill, 1996). Shallow lakes and reservoirs usually have an abundance of aquatic macrophytes, which reduces the effect of the rain on the detachment of periphytic biomass. However, despite the studied reservoir having high macrophyte coverage, the experimental apparatus away kept the leaves of macrophytes (mainly Nymphaea spp.) and, consequently, rain strongly 
contributed to the detachment of periphyton. Thus, we believe that high biomass accrual rates during the dry season were associated with low rainfall and changes in limnological conditions, especially TN concentration and water transparency.

The maximum biomass and time necessary to achieve it are very important characteristics in the study of periphyton dynamics (Stevenson, 1996). The literature suggests a colonization time of 20 to 30 days (2-4 wk) is ideal for periphyton to develop maximum biomass, and avoid subsequent sloughing (Cattaneo \& Amireault, 1992; Bicudo et al., 1995). However, the physical and chemical characteristics of substrates have a strong influence on periphyton biomass accumulation and, as a consequence, it is commonly questioned how well periphyton on artificial substrates represent natural conditions (Vadeboncoeur et al., 2006). In a review, Bicudo et al. (1995) reported greater periphyton biomass and primary production on macrophytes than on artificial substrates in a tropical ecosystem. Considering the same research period in the studied reservoir, maximum biomass $\left(1.9 \mu \mathrm{g} \mathrm{cm}^{-2}\right.$ ) found in 98 days of colonization was within the range recorded for periphyton on Utricularia foliosa L. (2.2 $\mu \mathrm{g} \mathrm{cm}^{-2}$; Santos et al., 2013). However, maximum biomass was higher than values recorded for Nymphaea spp. (84\%), Eleocharis acutangula (Roxb.) Schult (68\%) and Panicum repens L. (11\%) (Pellegrini \& Ferragut, 2012; Camargo \& Ferragut, 2014; Casartelli \& Ferragut, 2015). In addition, we also found that biomass maximum occurred after the exponential phase of biomass increment (dry season: 98th day; rainy season: 42 nd day), which occurred between 20 and 35 days of colonization. Thus, time to reach the maximum biomass can be greater than 30 days, as reported in both tropical and temperate reservoirs (Moschini-Carlos et al., 2000; Kralj et al., 2006). Good estimates for periphyton biomass on natural substrates are possible using artificial substrates, but the influence of colonization time on the development of periphyton should be considered.

Based on net and gross biomass accrual rate, we identified three phases of biomass accumulation during the colonization time (98 days): exponential, loss and fluctuation. The exponential phase of biomass accrual ended on the 28th day of the rainy season and on the 35 th day of the dry season. The period of negative accrual rate was denominated loss phase, which occurred between 84 and 91 days in the rainy season and 42 and 63 days in the dry season. According to Biggs (1996), the biomass accumulation pattern reflects changes in the primary process because the increment phase is controlled primarily by resource availability (nutrients, light), while the loss phase acts directly after the disturbance process (instability substrate, current velocity, suspended solids) and/or grazing (invertebrates and fish). The fluctuation phase was directly related to the disturbance regime being a fundamental determinant of the overall balance between accrual and loss processes (Biggs, 1996). Slight to moderate disturbances can have a positive effect on the increment of periphyton biomass mainly due to the removal of the senescent part, which promotes the exchange of water and light penetration into the deeper layers of the matrix (Peterson, 1996; Rodrigues \& Bicudo, 2004). Thus, phases of periphytic biomass accumulation showed that accrual and loss phases can be easily disrupted by a disturbance such as rainfall.

\section{Conclusion}

Our findings showed that the exponential phase of biomass accrual occurred within the colonization time commonly reported in the literature (28 to 35 days), but maximum biomass was detected only after 42 and 98 days during the rainy and dry period, respectively. Probably, the evaluation of the role of periphyton in the production of organic matter in tropical shallow lakes and reservoirs should consider the colonization time to be higher than 30 days.

The highest values of periphyton biomass and net and gross accrual rates were recorded during the dry season, which was characterized by high TN concentration and water transparency as well as low rainfall. As expected, the process of biomass accumulation was very dynamic, which certainly is one of the difficulties in establishing criteria for monitoring periphyton. Finally, we concluded that periphyton biomass accrual and the duration of the developmental phases (exponential, loss and fluctuation) changed with variations in limnological conditions and climatic conditions in the studied tropical shallow reservoir.

\section{Acknowledgements}

Authors are indebted to Fapesp (Fundação de Amparo a Pesquisa do Estado de São Paulo) for the fellowship given to G.J.L (grant No. 2010/17446-3) and CF thanks for the financial support (grant No. 2009/52253-4). Authors are also thankful to all students and technicians involved in the laboratory and fieldwork. 


\section{References}

AMERICAN PUBLIC HEALTH ASSOCIATION - APHA. Standard Methods for the Examination of Water and Wastewater. Washington: American Public Health Association, 2005.

BICUDO, C.E.M., CARMO, C.F., BICUDO, D.C., HENRY, R., PIÃO, A.C.S., SANTOS, C.M. and LOPES, M.R.M. Morfologia e morfometria de três reservatórios no PEFI. In D.C. BICUDO, M.C. FORTI and C.E.M. BICUDO, eds. Parque Estadual das Fontes do Ipiranga (PEFI): unidade de conservação que resiste à urbanização de São Paulo. São Paulo: Secretaria do Meio Ambiente do Estado de Sáo Paulo, 2002, pp. 143-160.

BICUDO, D.C., NECCHI, O. and CHAMIXAES, C.B.C.B. Periphyton studies in Brazil: present status and perspectives. In J.G. TUNDISI, C.E.M. BICUDO and T. MATSUMURA-TUNDISI, orgs. Limnology in Brazil. Rio de Janeiro: Academia Brasileira de Ciências, Sociedade Brasileira de Limnologia, 1995, pp. 37-58.

BIGGS, B.J.F. Patterns in benthic algae of streams. In R.J. STEVENSON, M.L. BOTHWELL and R.L. LOWE, eds. Algal Ecology: freshwater benthic ecosystems. San Diego: Academic Press, 1996, pp. 31-56.

BIGGS, B.J.F. Artificial substrate exposure times for periphyton biomass estimates in rivers. New Zealand Journal of Marine and Freshwater Research, 1998, 22(4), 507-515. http://dx.doi.org/10.1080/00288 330.1988 .9516321$.

CAMARGO, V.M. and FERRAGUT, C. Estrutura da comunidade de algas perifíticas em Eleocharis acutangula (Roxb.) Schult (Cyperaceae) em reservatório tropical raso, São Paulo, SP, Brasil. Hoehnea, 2014, 41(1), 31-40. http://dx.doi. org/10.1590/S2236-89062014000100003.

CASARTELLI, M.R. and FERRAGUT, C. Influence of seasonality and rooted aquatic macrophyte on periphytic algal community on artificial substratum in a shallow tropical reservoir. International Review of Hydrobiology, 2015, 100(5-6), 158-168. http:// dx.doi.org/10.1002/iroh.201401773.

CATTANEO, A. and AMIREAULT, M.C. How artificial are artificial substrate for periphyton? Journal of the North American Benthological Society, 1992, 11(2), 244-256. http://dx.doi.org/10.2307/1467389.

FELISBERTO, S. and RODRIGUES, L. Influência do gradiente longitudinal (rio-barragem) na similaridade das comunidades de desmídias perifíticas. Revista Brasileira de Botanica. Brazilian Journal of Botany, 2005, 28(2), 241-254. http://dx.doi.org/10.1590/ S0100-84042005000200005.

FRANÇA, R.C.S., LOPES, M.R.M. and FERRAGUT, C. Temporal variation of biomass and status nutrient of periphyton in a shallow Amazonian Lake (Rio
Branco, Brazil). Acta Limnologica Brasiliensia, 2009, 21(2), 175-183.

GOLTERMAN, H.L. and CLYMO, R.S. Methods for chemical analysis of freshwaters. Oxford: Blackwell Scientific Publications, 1971.

GOLTERMAN, H.L., CLYMO, R.S. and OHMSTAD, M.A.M. Methods for physical and chemical analysis of freshwaters. Oxford: Blackwell Scientific Publications, 1978.

HILL, W.R. Effects of light. In R.J. STEVENSON, M.L. BOTHWELL and R.L. LOWE, eds. Algal Ecology: freshwater benthic ecosystems. San Diego: Academic Press, 1996, pp. 121-148.

KRALJ, K., PLENKOVIC-MORAJ, A., GLIGORA, M., PRIMC-HABDIJA, B. and SIPOS, L. Structure of periphytic community on artificial substrates: influence of depth, slide orientation and colonization time in karstic Lake Visovacko, Croatia. Hydrobiologia, 2006, 560(1), 249-258. http://dx.doi. org/10.1007/s10750-005-1330-y.

MCCUNE, B. and MEFFORD, M.J. PC-ORD. Multivariate analysis of ecological data. Gleneden Beach: MjM Software, 2011.

MOSCHINI-CARLOS, V., HENRY, R. and POMPÊO, M.L.M. Seasonal variation of biomass and productivity of the periphytic community on artificial substrates in the Jurumirim Reservoir (São Paulo, Brazil). Hydrobiologia, 2000, 434(1), 35-40. http://dx.doi.org/10.1023/A:1004086623922.

PELLEGRINI, B.G. and FERRAGUT, C. Variação sazonal e sucessional da comunidade de algas perifíticas em substrato natural em um reservatório mesotrófico tropical. Acta Botanica Brasilica, 2012, 26(4), 807-818. http://dx.doi.org/10.1590/S010233062012000400010.

PETERSON, C.G. Mechanisms of lotic microalgal colonization following space-clearing disturbances acting at different spatial scales. Oikos, 1996, 77(3), 417-435. http://dx.doi.org/10.2307/3545932.

RODRIGUES, L. and BICUDO, D.C. Periphytic Algae. In A.A. AGOSTINHO, M. THOMAZ and N.S. HAHN, orgs. The Upper Paraná River and its Floodplain: physical aspects, ecology and conservation. Leiden: Backhuys, 2004, pp. 125-143.

SANTOS, T.R., FERRAGUT, C. and BICUDO, C.E.M. Does macrophyte architecture influence periphyton? Relationships among Utricularia foliosa, periphyton assemblage structure and its nutrient $(\mathrm{C}$, N, P) status. Hydrobiologia, 2013, 714(1), 71-83. http://dx.doi.org/10.1007/s10750-013-1531-8.

SARTORY, D.P. and GROBBELAAR, J.E. Extraction of chlorophyll $a$ from freshwater phytoplankton for spectrophotometric analysis. Hydrobiologia, 1984, 114(3), 177-187. http://dx.doi.org/10.1007/ BF00031869. 
STEVENSON, R.J. An introduction to algal ecology in freshwater benthic habits. In R.J. STEVENSON, M.L. BOTHWELL and R.L. LOWE, eds. Algal Ecology: freshwater benthic ecosystems. San Diego: Academic Press, 1996, pp. 3-30.

UNIVERSIDADE DE SÃO PAULO - USP. Instituto de Astronomia e Geofísica. Estação meteorológica [online] São Paulo: USP, 2015 [viewed 19 Jan. 2015]. Available from: estacao.iag.usp.br

VADEBONCOEUR, Y. and STEINMAN, A.D. Periphyton function in lake ecosystems. TheScientific WorldJournal, 2002, 2, 1449 1468. http://dx.doi.org/10.1100/tsw.2002.294. PMid:12805932.

VADEB O N C OEUR, Y., KALFF, J., CHRISTOFFERSEN, K. and JEPPESEN, E. Substratum as a driver of variation in periphyton chlorophyll and productivity in lakes. Journal of the North American Benthological Society, 2006, 25(2), 379-392. http://dx.doi.org/10.1899/08873593(2006)25[379:SAADOV]2.0.CO;2.

VALDERRAMA, J.C. The simultaneous analysis of total nitrogen and total phosphorus in natural waters. Marine Chemistry, 1981, 10(2), 109-122. http:// dx.doi.org/10.1016/0304-4203(81)90027-X.

VERCELLINO, I.S. and BICUDO, D.C. Sucessão da comunidade de algas perifíticas em reservatório oligotrófico tropical (São Paulo, Brasil): Comparação entre período seco e chuvoso. Revista Brasileira de Botanica. Brazilian Journal of Botany, 2006, 29(3), 363-377. http://dx.doi.org/10.1590/S010084042006000300004 .

Received: 19 January 2016 Accepted: 27 July 2016 